\title{
OBSERVATIONS ON THE INCIDENCE OF UPPER RESPIRATORY INFECTIONS IN A ROYAL AIR FORCE FORMATION IN SOUTHERN RHODESIA
}

\author{
BY \\ W. B. THORBURN, WG. CDR. R.A.F. \\ From the Directorate of Hygiene and Research, Air Ministry
}

The upper respiratory infections are among the commonest causes of morbidity in general. Apart from this, they have their own particular importance in the Royal Air Force, because of their influence on the efficiency of those who fly. Pilots and their fellow aircrew members are repeatedly subjected to sudden changes in atmospheric pressure during rapid ascent and descent in flight. Congestion of the respiratory passages may incapacitate them by preventing the normal response of nasal sinuses and Eustachian tubes to such changes.

Concern was felt in 1952 at the prevalence of upper respiratory infections among flying personnel in the Rhodesian Air Training Group (R.A.T.G.), of which the writer was Senior Medical Officer at the time. It was in addition observed that the incidence of the upper respiratory infections in the Group as a whole was higher than in any comparable formation at home or abroad. In 1951, for example, the incidence was 88 per thousand per annum compared with 61 in the Middle East, 58 in Germany, and 62 in a command with equivalent functions in England. It was decided to investigate the reasons for the high incidence in R.A.T.G. in general and among flying personnel in particular.

\section{Methods}

Previous work in the R.A.F. had concentrated more on the experimental control of these infections; for example the Halton experiment (Macdonald, Tonkinson, Portafield, and Dumbell, 1955) was then current. There were no facilities in R.A.T.G. for anything elaborate of a similar nature, so it was decided to analyse the sickness and personnel records of all cases admitted to sick quarters or hospital or confined to bed at home because of upper respiratory infections, during the years 1947 to 1952 inclusive.

An admission was defined as a case sufficiently severe to be in sick-quarters or hospital or at home in bed for over 48 hours. The main reason for limiting the investigation to admissions was that it would eliminate over-readiness to report sick as a cause of increased incidence. Those with trivial complaints are not put to bed for over 48 hours; those requiring such treatment are most unlikely to stay away from the doctor.

Upper respiratory infections were classified as acute tonsillitis, acute sinusitis, and the group comprising coryza, nasopharyngitis, pharyngitis, laryngitis, and tracheitis. In multiple diagnoses, of which there were not a great number, only the major infection counted. The information obtained was analysed according to a number of social and environmental circumstances, which it was hoped might throw light on the high incidence of upper respiratory infections in R.A.T.G. as a whole and among flying personnel in particular.

\section{RESULTS}

Prevalence.-Table I (opposite) shows the total cases of tonsillitis, sinusitis, and other upper respiratory infections that occurred in the R.A.F. in Southern Rhodesia during the period 1947 to 1952. The incidence for the whole population for this period was $76 \cdot 1$ per thousand per annum; tonsillitis, with an incidence of $38 \cdot 9$, was responsible for more than half the cases. This Table also shows the breakdown of the population into flying personnel (360) and ground personnel $(1,889)$. There is a marked disparity between the incidence of upper respiratory infections in these two groups: $155 \cdot 1$ in 
aircrew, 61.0 in ground personnel. The standard error of the difference between these proportions is $8 \cdot 1$, so that the difference is unlikely to be due to chance. Aircrew show a higher incidence of tonsillitis; but the difference between the incidences in aircrew and ground personnel of other upper respiratory infections is greater.

TABLE I

AVERAGE INCIDENCE OF UPPER RESPIRATORY INFECTIONS 1947 TO 1952

(per 1,000 per annum)

\begin{tabular}{|c|c|c|c|c|c|c|}
\hline \multirow[t]{2}{*}{ Infection } & \multicolumn{2}{|c|}{$\begin{array}{c}\text { Flying } \\
\text { Personnel } \\
\text { (Strength 360) }\end{array}$} & \multicolumn{2}{|c|}{$\begin{array}{c}\text { Ground } \\
\text { Personnel } \\
\text { (Strength } 1,889)\end{array}$} & \multicolumn{2}{|c|}{$\begin{array}{c}\text { Total } \\
\text { (Strength 2,249) }\end{array}$} \\
\hline & Cases & Incidence & Cases & Incidence & Cases & Incidence \\
\hline $\begin{array}{l}\text { Tonsillitis } \\
\text { Sinusitis . . } \\
\text { Others . }\end{array}$ & $\begin{array}{r}139 \\
43 \\
153\end{array}$ & $\begin{array}{l}64 \cdot 3 \\
19 \cdot 9 \\
70 \cdot 8\end{array}$ & $\begin{array}{r}386 \\
81 \\
225\end{array}$ & $\begin{array}{r}34 \cdot 0 \\
7 \cdot 1 \\
19 \cdot 8\end{array}$ & $\begin{array}{l}525 \\
124 \\
378\end{array}$ & $\begin{array}{r}38 \cdot 9 \\
9 \cdot 2 \\
28 \cdot 0\end{array}$ \\
\hline Total .. & 335 & $155 \cdot 1$ & 692 & $61 \cdot 0$ & 1,027 & $76 \cdot 1$ \\
\hline
\end{tabular}

Note: In Tables I to III the strength is the average for the years concerned; the cases are totals for the period.

Age.-Table II gives the incidence of upper respiratory infections in flying and ground personnel by age groups. In the population as a whole the younger age groups (under 30 years old), and in particular those under 20 years, suffered most from these infections. The incidence was 85 per thousand per annum in the under thirties and 46 in those aged 30 and over $(D=39 ; S . E .=4 \cdot 7)$. The Table also gives the incidence in aircrew standardized for age.
The higher incidence among them is not accounted for by the age distribution.

Length of Tour.-The R.A.F. tour of duty in Southern Rhodesia was $\mathbf{3 0}$ months for regulars, 18 months for National Service men, and 9 months for aircrew under training. The incidence of upper respiratory infections at various stages of the tour is shown in Table III. Figures were available only for 1951 and 1952. The incidence among ground personnel was lowest at 10 to 18 months.

Since National Service airmen spent 18 months in R.A.T.G., there was probably little difference in the age distribution among ground personnel during the first and second 9-month period of the tour. The figures suggest increased susceptibility to upper respiratory infection during the first few months spent in Rhodesia. In fact, during the first 3 months the incidence was 116 per thousand per annum. The population in the third period of 9 months consisted of regulars only, so is not comparable. The figures for aircrew in the second and third 9-month periods are too small to be reliable. In any case they are not comparable with those for the first 9 months, when about 70 per cent. of the aircrew population consisted of pupils. It is noteworthy, however, that when aircrew are included with ground personnel, the ground incidence (in the first 9 months) of 80 per thousand is raised to a total incidence of 100 per thousand per annum. This 25 per cent. increase is an indication of the influence of the 9-month tour of aircrew pupils on the whole incidence in R.A.T.G.

TABLE II

AGE DISTRIBUTION OF UPPER RESPIRATORY INFECTIONS 1947 TO 1952

(Incidence per 1,000 per annum)

\begin{tabular}{|c|c|c|c|c|c|c|c|c|c|}
\hline \multirow{2}{*}{$\begin{array}{c}\text { Age } \\
\text { (yrs) }\end{array}$} & \multicolumn{3}{|c|}{ Flying Personnel } & \multicolumn{3}{|c|}{ Ground Personnel } & \multicolumn{3}{|c|}{ Total } \\
\hline & Strength & Cases & Incidence & Strength & Cases & Incidence & Strength & Cases & Incidence \\
\hline $\begin{array}{c}\text { Under } 20 \\
20-24 \\
25-29 \\
30-34 \\
35 \text { and over }\end{array}$ & $\begin{array}{r}82 \\
156 \\
57 \\
52 \\
13\end{array}$ & $\begin{array}{r}124 \\
99 \\
66 \\
27 \\
19\end{array}$ & $\begin{array}{r}252 \\
106 \\
193 \\
86 \\
244\end{array}$ & $\begin{array}{r}201 \\
1,025 \\
231 \\
202 \\
230\end{array}$ & $\begin{array}{r}165 \\
293 \\
144 \\
53 \\
37\end{array}$ & $\begin{array}{r}137 \\
48 \\
104 \\
44 \\
27\end{array}$ & $\begin{array}{r}283 \\
1,181 \\
288 \\
254 \\
243\end{array}$ & $\begin{array}{r}289 \\
392 \\
210 \\
80 \\
56\end{array}$ & $\begin{array}{r}170 \\
55 \\
121 \\
52 \\
38\end{array}$ \\
\hline Total .. & 360 & 335 & 155 & 1,889 & 692 & 61 & 2,249 & 1,027 & 76 \\
\hline
\end{tabular}

Standardized against the ground personnel age distribution, the incidence for flying personnel becomes 149 .

TABLE III

INCIDENCE OF UPPER RESPIRATORY INFECTION BY LENGTH OF TOUR, 1951 TO 1952

\begin{tabular}{|c|c|c|c|c|c|c|c|c|c|}
\hline \multirow{2}{*}{$\begin{array}{c}\text { Length of } \\
\text { Tour } \\
\text { (mths) }\end{array}$} & \multicolumn{3}{|c|}{ Flying Personnel } & \multicolumn{3}{|c|}{ Ground Personnel } & \multicolumn{3}{|c|}{ Total } \\
\hline & Strength & Cases & $\begin{array}{c}\text { Incidence } \\
\text { (per } 1,000 \\
\text { per annum) }\end{array}$ & Strength & Cases & $\begin{array}{c}\text { Incidence } \\
\text { (per } 1,000 \\
\text { per annum) }\end{array}$ & Strength & Cases & $\begin{array}{c}\text { Incidence } \\
\text { (per 1,000 } \\
\text { per annum) }\end{array}$ \\
\hline $\begin{array}{r}0-9 \\
10-18 \\
19-27\end{array}$ & $\begin{array}{r}326 \\
43 \\
18\end{array}$ & $\begin{array}{l}95 \\
16 \\
12\end{array}$ & $\begin{array}{l}146 \\
186 \\
333\end{array}$ & $\begin{array}{l}766 \\
943 \\
407\end{array}$ & $\begin{array}{r}123 \\
94 \\
62\end{array}$ & $\begin{array}{l}80 \\
50 \\
76\end{array}$ & $\begin{array}{r}1,092 \\
986 \\
425\end{array}$ & $\begin{array}{r}218 \\
110 \\
74\end{array}$ & $\begin{array}{r}100 \\
56 \\
87\end{array}$ \\
\hline
\end{tabular}


Domestic Environment.-No social or domestic factor was observed that could account for the high incidence of upper respiratory infections in flying personnel. None of them slept more than two in a room. Their living accommodation in messes was good. On the other hand a large proportion of ground personnel occupied twenty-bedded dormitories. This should in theory have facilitated the spread of infection among them. As a whole living conditions favoured aircrew.

Occupational Factor.-The lower incidence of upper respiratory infections among ground personnel (Table I) suggests that an occupational factor might be a cause of the higher incidence in aircrew. Of the 1,889 ground personnel, 952 men were concerned with aircraft engineering or maintenance; their occupational environment corresponded broadly with that of aircrew on the ground. Among them there were 316 cases of upper respiratory infection, an incidence of 55.3 per thousand per annum. Among the remaining 937 ground personnel, who had little or nothing to do with aircraft, there were 376 cases, an incidence of 66.9 . This suggests that if there was some occupational factor, it was unconnected with the work of aircrew on the ground.

Complete figures for upper respiratory infections in families were not available for the whole period of observation. But among 100 wives of aircrew in 1951, there were ten cases that could be classed as admissions because of such infections. This gives an incidence of 100 per thousand per annum, while in the same year the incidence among their husbands was 189. The sample is small and the difference could be due to chance or to reasons unrelated to occupation. However, as evidence, this difference does fit in with the other factors pointing to the operation of an occupational factor among aircrew.

Oxygen Masks.-Training aircraft in R.A.T.G. had no oxygen systems, but masks incorporating microphones were worn by aircrew for radio com- munication. This might suggest that "oxygen" masks were a possible vehicle for the spread of infection from man to man. The masks were, however, an individual issue and inquiry showed that there was no common usage. In addition the masks were cleaned periodically and, if returned to stores, were disinfected before reissue to another person.

Climate.-The respiratory tract of the occupant of an aircraft in flight is subjected to changes in temperature, pressure, and other atmospheric conditions. Evidence of the effects of such changes on susceptibility, it was reasoned, might be found if any association could be shown between ground climatic conditions and the prevalence of upper respiratory infections in general. Such evidence might help to confirm the suspected occupational susceptibility of aircrew.

The number of cases of upper respiratory infection occurring each month during the period of observation was standardized to the average population of 2,249 , i.e. the number was increased or decreased according to the proportion between the actual monthly population and the average population for the whole period of observation. The mean values for each month were then correlated with the mean meteorological data for the same period. The information obtained in this way is set out at Table IV, and the relevant coefficients of correlation in Table V (opposite).

There is no correlation between upper respiratory infections as a whole or between other infections and climatic conditions. There is some inverse correlation between tonsillitis and absolute humidity both in the same month (co-efficient -0.56 ) and in the previous month (co-efficient - 0.61). Sinusitis shows some positive association with the mean minimum temperature of the previous month (co-efficient $+0 \cdot 57$ ). Taking a level of significance for the correlation of 12 pairs of \pm 0.576 (Fisher and Yates, 1948), only the second of these

TABLE IV

COMPARISON OF UPPER RESPIRATORY INFECTION WITH METEOROLOGICAL CONDITIONS, 1947-1952

\begin{tabular}{|c|c|c|c|c|c|c|c|c|c|}
\hline \multicolumn{3}{|c|}{ Month } & \multicolumn{4}{|c|}{ No. of Cases } & \multirow{2}{*}{$\begin{array}{c}\text { Mean } \\
\text { Absolute } \\
\text { Humidity } \\
\text { (g./cu. m.) }\end{array}$} & \multicolumn{2}{|c|}{ Mean Temperature ( $\left.{ }^{\circ} \mathrm{F}.\right)$} \\
\hline & & & Total & Tonsillitis & Sinusitis & Other & & Maximum & Minimum \\
\hline $\begin{array}{l}\text { January .. } \\
\text { February } \\
\text { March } \\
\text { April .. } \\
\text { May } \quad . . \\
\text { June } \quad \ldots \\
\text { July } \\
\text { August } \\
\text { September } \\
\text { October... } \\
\text { November } \\
\text { December }\end{array}$ & $\begin{array}{l}\ldots \\
\cdots \\
\cdots \\
\cdots \\
\cdots \\
\cdots \\
\cdots \\
\cdots\end{array}$ & $\begin{array}{l}\ldots \\
\ldots \\
\cdots \\
\cdots \\
\ldots \\
\ldots \\
\cdots \\
\cdots \\
\ldots\end{array}$ & $\begin{array}{r}75 \\
81 \\
67 \\
92 \\
88 \\
86 \\
91 \\
76 \\
75 \\
90 \\
107 \\
98\end{array}$ & $\begin{array}{l}35 \\
41 \\
31 \\
48 \\
42 \\
39 \\
50 \\
43 \\
51 \\
54 \\
51 \\
37\end{array}$ & $\begin{array}{r}16 \\
17 \\
11 \\
12 \\
12 \\
8 \\
11 \\
4 \\
3 \\
10 \\
19 \\
3\end{array}$ & $\begin{array}{l}24 \\
23 \\
25 \\
32 \\
34 \\
39 \\
30 \\
29 \\
21 \\
26 \\
37 \\
58\end{array}$ & $\begin{array}{l}10 \cdot 4 \\
10 \cdot 1 \\
10 \cdot 4 \\
8 \cdot 1 \\
6 \cdot 5 \\
5 \cdot 3 \\
4 \cdot 5 \\
4 \cdot 5 \\
5 \cdot 1 \\
6 \cdot 3 \\
8 \cdot 6 \\
9 \cdot 1\end{array}$ & $\begin{array}{l}79 \\
80 \\
80 \\
78 \\
71 \\
69 \\
70 \\
76 \\
82 \\
84 \\
81 \\
81\end{array}$ & $\begin{array}{l}60 \\
58 \\
59 \\
55 \\
49 \\
46 \\
46 \\
48 \\
54 \\
60 \\
60 \\
62\end{array}$ \\
\hline
\end{tabular}


associations is established. The association of climate and infections in aircrew was similarly tested. Neither tonsillitis, sinusitis, or other upper respiratory infections were found to correlate at all with any climatic condition, the coefficients in each case being less than $\pm 0 \cdot 4$.

\section{Discussion}

There were two questions to which answers were sought. Why did the R.A.F. have a higher incidence of upper respiratory infections in Southern Rhodesia than in other theatres? Why were aircrew the worst afflicted by these infections?

Downes (1952) remarked on the tendency for susceptibility to upper respiratory infection to decrease with age. This is common experience in the Royal Air Force as a whole and the pattern of infection in R.A.T.G. was no different. Aircrew pupils belonged to particularly vulnerable age groups.

Aircrew pupils were additionally vulnerable because they were relatively unacclimatized and because they flew. On account of their 9 months tour of duty, this most susceptible group was constantly reinforced. In this respect R.A.T.G. was unique among R.A.F. formations abroad. The higher general incidence of upper respiratory infections among the R.A.F. in Rhodesia may have been due in part to this circumstance.

Charters (1951) drew attention to the prevalence of sinusitis and sore throats among Europeans living at high altitudes in Kenya. He attributed this to the low humidity and consequent drying of the upper respiratory mucosa. Waddy (1952) demonstrated that the prevalence of airborne infections, such as cerebrospinal fever and lobar pneumonia, varied inversely as the absolute humidity of the previous month. Acute tonsillitis among the R.A.F. in Southern Rhodesia appeared to follow a similar pattern. The altitude of the R.A.T.G. stations was approximately 4,500 feet, and for 6 months of the year the mean absolute humidity was $6.5 \mathrm{~g}$. per cu. m. or less (Table VI). In contrast, the majority of the R.A.F. stations abroad are low lying, many being near coasts, and few being likely to experience absolute humidities as low as those in R.A.T.G. The figures for Cyprus and Singapore illustrate the contrast. The dry climate of Rhodesia may have been another factor responsible for the high rate of acute tonsillitis among R.A.F. personnel who served there.

\begin{tabular}{|c|c|c|c|c|}
\hline \multicolumn{5}{|c|}{$\begin{array}{c}\text { TABLE VI } \\
\text { MEAN ABSOLUTE HUMIDITY VALUES COMPARED } \\
\text { (g./cu. m.) }\end{array}$} \\
\hline Month & $\begin{array}{c}\text { Southern } \\
\text { Rhodesia } \\
\text { at Ground Level } \\
(4,500 \mathrm{ft} .)\end{array}$ & $\begin{array}{l}\text { At } \\
\text { High Altitudes } \\
\text { over Southern } \\
\text { Rhodesia } \\
(14,500 \mathrm{ft} .)\end{array}$ & $\begin{array}{c}\text { Cyprus } \\
\text { at } \\
\text { Sea Level }\end{array}$ & $\begin{array}{c}\text { Singapore } \\
\text { at } \\
\text { Sea Level }\end{array}$ \\
\hline $\begin{array}{l}\text { January... } \\
\text { February } \\
\text { March .. } \\
\text { April } . . \\
\text { May } \quad . \\
\text { June } \quad . \\
\text { July } \quad . \\
\text { August .. } \\
\text { September } \\
\text { October.. } \\
\text { November } \\
\text { December }\end{array}$ & $\begin{array}{r}10 \cdot 4 \\
10 \cdot 1 \\
10 \cdot 4 \\
8 \cdot 1 \\
6 \cdot 5 \\
5 \cdot 3 \\
4 \cdot 5 \\
4 \cdot 5 \\
5 \cdot 1 \\
6 \cdot 3 \\
8 \cdot 6 \\
9 \cdot 1\end{array}$ & $\begin{array}{l}3 \cdot 9 \\
3 \cdot 9 \\
3 \cdot 4 \\
2 \cdot 5 \\
2 \cdot 0 \\
2 \cdot 0 \\
2 \cdot 0 \\
1 \cdot 9 \\
2 \cdot 2 \\
2 \cdot 7 \\
3 \cdot 3 \\
3 \cdot 5\end{array}$ & $\begin{array}{r}6 \cdot 2 \\
6 \cdot 2 \\
6 \cdot 7 \\
7 \cdot 6 \\
9 \cdot 0 \\
10 \cdot 4 \\
12 \cdot 3 \\
12.9 \\
11 \cdot 2 \\
9 \cdot 8 \\
8 \cdot 4 \\
6 \cdot 7\end{array}$ & $\begin{array}{l}17 \cdot 4 \\
16 \cdot 2 \\
16 \cdot 2 \\
16 \cdot 2 \\
17.9 \\
17 \cdot 4 \\
16 \cdot 2 \\
16 \cdot 2 \\
16 \cdot 2 \\
16 \cdot 2 \\
15 \cdot 4 \\
15 \cdot 4\end{array}$ \\
\hline
\end{tabular}

Upper respiratory infections as a whole did not correlate with climate. This was because the associations of the different infections cancelled each other out. It was thought that this might also be the reason for the lack of correlation between climate and the group of other infections, in which coryza, pharyngitis, naso-pharyngitis, laryngitis, and tracheitis were all treated as one. For this reason it was the intention to collect further information on each infection in this group, progressively. With larger numbers of the individual infections in the group, it would have been possible to test climatic correlations further. Some explanation for the large difference in the incidence of this group in aircrew and ground personnel might also have come to light. But R.A.T.G. was closed down, and as a result, the work was brought to an end.

TABLE V

COEFFICIENTS OF CORRELATION BETWEEN CLIMATIC DATA AND UPPER RESPIRATORY INFECTIONS

\begin{tabular}{|c|c|c|c|c|c|c|c|c|}
\hline \multirow{2}{*}{\multicolumn{3}{|c|}{ Infection }} & \multirow{2}{*}{\multicolumn{2}{|c|}{ Absolute Humidity }} & \multicolumn{4}{|c|}{ Mean Temperature } \\
\hline & & & & & \multicolumn{2}{|c|}{ Maximum } & \multicolumn{2}{|c|}{ Minimum } \\
\hline & & & Same Month & Previous Month & Same Month & Previous Month & Same Month & Previous Month \\
\hline Tonsillitis & . & $\ldots$ & -0.5617 & -0.6119 & +0.1434 & -0.0362 & -0.1299 & $-0 \cdot 3714$ \\
\hline Sinusitis & .. & $\ldots$ & +0.5416 & +0.4468 & +0.0359 & +0.4565 & $+0 \cdot 2811$ & $+0 \cdot 5706$ \\
\hline Other & .. & $\ldots$ & +0.0424 & +0.0780 & -0.1526 & +0.0894 & +0.0706 & $+0 \cdot 1749$ \\
\hline Total ... & $\ldots$ & $\ldots$ & -0.0702 & -0.1157 & -0.0267 & +0.2724 & +0.1119 & $+0 \cdot 1856$ \\
\hline
\end{tabular}


Neither age, length of tour, or social environment account for the difference in incidence between flying and ground personnel. On the ground, aircrew were exposed to the same climatic conditions as everyone else. Unless actually flying their occupational environment differed little from that of ground personnel working on aircraft, and the oxygen mask can be disregarded as a factor increasing the spread of infection among them. It seems the inevitable conclusion that there must have been some factor or set of factors connected with flight that increased the susceptibility of aircrew to upper respiratory infec- tions.

Practically every day aircrew flew to about 10,000 feet, without oxygen, and remained in the air for varying periods. Often more than one flight was carried out in a day. These men, therefore, continually breathed air of low humidity, irrespective of ground climatic conditions. The absolute humidities of the air at high altitudes are given in Table VI. It seems likely that drying of the respiratory mucosa was the factor which increased aircrew susceptibility to acute tonsillitis. Supporting evidence is the lack of correlation between tonsillitis in aircrew and climatic absolute humidity; the mucosa was dried in flight irrespective of conditions on the ground.

It is concluded that the causes contributing to a high rate of upper respiratory infections in R.A.T.G. included the dry climate and the continuous turnover of aircrew under training. The high incidence of tonsillitis in aircrew was probably connected with the constant drying of the upper respiratory mucosa caused by flying at high altitudes. When this inquiry came to a premature end, insufficient information had been assembled from which to draw conclusions about sinusitis and the other upper respiratory infections.

\section{SUMMARY}

(1) From 1947 to 1952 , the incidence of upper respiratory infections among R.A.F. personnel in
Southern Rhodesia was higher than among those serving in other parts of the world. These infections were particularly prevalent in aircrew. Acute tonsillitis was the commonest infection.

(2) The effects of age distribution and length of tour on the incidence of upper respiratory infections suggest that the constant reinforcement of R.A.T.G. by aircrew pupils was one possible reason for the high rate.

(3) The study of the domestic and occupational environment of aircrew and ground personnel gives evidence that an occupational factor related to flying might be responsible for the high incidence of upper respiratory infections in the former.

(4) The study of climatic conditions in relation to the infections points to dryness of the atmosphere (low absolute humidity) as a factor increasing susceptibility to acute tonsillitis.

(5) Aircrew were constantly exposed to low absolute humidities at high altitudes during flight. This is the probable occupational factor responsible for the prevalence of tonsillitis among them.

(6) There is insufficient information to reach conclusions on sinusitis and the other upper respiratory infections.

I am indebted to the Southern Rhodesian Government Meteorological Office, Bulawayo, for the climatic data. I wish to acknowledge the help of Wing Commander J. D. Tonkinson, Air Ministry (M.A.7), with the preparation of the statistics in the paper, and to thank Professor A. Bradford Hill for his advice on them. My thanks are due for permission to publish this paper to the Director General of Medical Services, Royal Air Force.

\section{REFERENCES}

Charters, A. D. (1951). E. Afr. med. J., 28, 174.

Downes, J. (1952). Milbank mem. Fd. Quart., 30, 211.

Fisher, R. A., and Yates, F. (1948). "Statistical Tables for Biological, Agricultural and Medical Research", 3rd ed. Oliver and Boyd, Edinburgh.

Macdonald, T. C., Tonkinson, J. D., Porterfield, J., and Dumbell, K. R. (1955). British Journal of Preventive and Social Medicine, 9, 33 .

Waddy, B. B. (1952). Lancet, 2, 674. 